интегрального образовательного пространства : дис.. ... канд. пед. наук : 13.00.01 / Лейсан Наиловна Фаткуллова. - Казань, 2010. - 245 с. 5. Халабузар О. А. Формування культури логічного мислення майбутнього вчителя у процесі фахової підготовки : дис. ... канд. пед. наук : 13.00.04 / Оксана Анатоліївна Халабузар. - Бердянськ, 2008. - 319 с.

Тетяна Плачинда

\title{
ПРОФЕСІЙНА РЕФЛЕКСІЯ ЯК УМОВА СТАНОВЛЕННЯ МАЙБУТНЬОГО ФАХІВЦЯ
}

Плачинда Т. С. Професійна рефлексія як умова становлення майбутнього фахівця.

Аналізуються поняття «рефлексія», «професійна рефлексія». Вивчаються думки науковців щодо ролі рефлексивного компонента в навчально-виховному процесі майбутніх фахівців. Подано авторське тлумачення поняття «рефлексія». Наведено дані тестування курсантів льотних навчальних закладів щодо рівнів сформованості професійної рефлексії. Говориться про те, що за умови формування у студентів навичок рефлексії, майбутній фахівець буде висококваліфікованим та конкурентоспроможним на ринку праці як в Україні, так і міжнародному співтоваристві.

Ключові слова: майбутній фахівець, рефлексія, професійна рефлексія, самоорганізація, навчально-професійна діяльність.

Плачинда Т. С. Профессиональная рефлексия как условие становления будущего специалиста.

Анализируются понятия «рефлексия», «профессиональная рефлексия». Изучаются позиции ученых о роли рефлексивного компонента в учебно-воспитательном процессе будущих специалистов. Представлено авторское толкование понятия «рефлексия». Приведены данные тестирования курсантов летных учебных заведений относительно уровней сформированности профессиональной рефлексии. Говорится о том, что в условиях формирования у студентов навыков рефлексии, будущий специалист будет высококвалифицированным и конкурентоспособным на рынке труда как в Украине, так и в международном сообществе.

Ключевые слова: будущий специалист, рефлексия, профессиональная рефлексия, самоорганизация, учебно-профессиональная деятельность.

Plachynda T. S. Professional reflection as a condition of future specialist development.

The defenitions of «reflection» and «professional reflection» are analyzed. Scientists' opinions about the role of the reflexive component in the educational process of future specialists are studied. The author's interpretation of the term «reflection» is given as well as the data of testing the flight cadets concerning the levels of professional reflection development. It is also stated that in the conditions of students' reflection skills formation, the future specialist will be highly skilled and competitive on labour market both in Ukraine and in the international community.

Key words: future specialist, reflection, professional reflection, self-organization, training and professional activity.

Глобалізація економіки, формування інформаційного суспільства та інтеграція 
системи української професійної освіти до європейського освітнього простору зумовлює зміни в сучасній освітній діяльності. Сьогодення вимагає удосконалення механізмів інтеграції вищих навчальних закладів України до міжнародної освітньої системи, підготовку майбутніх фахівців до професійного спілкування з урахуванням вимог міжнародного рівня тощо, тому в сучасних умовах становлення вищої професійної освіти набуває важливого значення не освіченість, а здатність фахівця реалізовувати ії у процесі здійснення конкретної практичної діяльності. Зважаючи на це, постає питання необхідності формування навичок рефлексії у майбутніх фахівців з метою їхньої конкурентоспроможності на ринку праці як в Україні, так і у світовому співтоваристві.

Увага науковців і практиків до осмислення сутності рефлексії зумовлена вимогами суспільства, зростанням потреби людини в самостійності, розумінні й оцінюванні себе. На сучасному етапі розвитку рефлексія постає як методологічна основа різних наукових напрямів. Проблему формування рефлексивних здібностей учнів та їхньої значущості в освітньому процесі досліджено в наукових працях Л. Виготського, В. Давидова, О. Жирун, С. Литвиненко, М. Марусинець, О. Мирошник, І. Семенова, С. Степанова, Л. Шихова та ін. Науковці підготували потужний фонд, представлений теоретичним і практично орієнтованим матеріалом із формування й розвитку рефлексивних умінь у навчальній діяльності. Водночас потребує системного дослідження питання щодо формування у майбутніх фахівців навичок професійної рефлексії.

Meта статmі: проаналізувати думки науковців щодо дефініції «рефлексія»; з'ясувати роль рефлексії у формуванні конкурентоспроможного фахівця; подати дані експерименту 3 формування навичок рефлексії у курсантів льотних навчальних закладів.

Згідно з наказом Міністерства освіти і науки від 26 січня 2015 року № 47 «Про особливості формування навчальних планів на 2015/2016 навчальний рік» [7] та окремих норм Закону України «Про вищу освіту» [1] на самостійну роботу студентів відводиться до $2 / 3$ кредиту ССТС, у зв'язку з чим постає питання щодо формування в майбутніх фахівців навичок рефлексії. Організація навчально-виховного процесу за принципами управління рефлексії в ході професійної підготовки майбутніх фахівців передбачає формування у спільній діяльності викладачів і студентів самопізнання та здатності до самоорганізації. Рефлексія - основа саморегуляції, що вможливлює ii розвиток і необхідна майбутнім фахівцям для самостійного усвідомлення нового навчального завдання, для розуміння своїх обмежень, а також наявних особистісних та індивідуальних ресурсів.

У науковій літературі обгрунтовано низку позицій стосовно тлумачення терміна «рефлексія». Рефлексія (від латинського reflexio - звернення назад) - роздум, самоспостереження. У філософському розумінні це форма теоретичної діяльності людини, спрямована на осмислення власних дій i їхніх законів [6]. Рефлексія - процес переосмислення та перетворення цінностей, норм, методів роботи й способів мислення, процес переоцінювання минулого та сьогодення [5, с. 133-138].

Для осмислення значущості рефлексивного механізму у формуванні саморегуляції навчальної діяльності необхідно з'ясувати, як і з якими об'єктами працює рефлексія. За об'єктом роботи диференціюють три форми рефлексії [8]: в образі дії, у сфері самосвідомості, у професійній діяльності. Перша форма відповідає за правильне застосування принципів дій, із якими студент уже ознайомлений (аналіз способів діяльності, мислення, технік, стратегій, застосовуваних для досягнення цілей). Для ефективної реалізації рефлексії у сфері самосвідомості необхідний досвід, який виявляється в умінні налагоджувати взаємини з іншими людьми, досягненні певних комунікативних цілей тощо. 
Третя форма пов'язана 3 професійною діяльністю. На наш погляд, для становлення усвідомленої самоорганізації навчальної діяльності студентів необхідні всі форми рефлексії, особливо важлива для майбутніх фахівців форма, яка стосується професійної діяльності.

О. Мирошник розглядає рефлексію як функцію свідомості, спрямованої на самопізнання певних перешкод, що виникають у предметній діяльності, соціальнопсихологічній взаємодії або проблемній ситуації. Ця функція активується внаслідок загострення внутрішніх і зовнішніх суперечностей, за наявності когнітивного конфлікту й забезпечує зміну позиції особистості до себе як суб'єкта пізнання, діяльності і спілкування. Продуктом рефлексії є пошук і створення особистістю нових смислів, цінностей як якісних складових самосвідомості особистості, що істотно змінюють ії ставлення до себе, до інших і предметної ситуації. Результатом рефлексії $\epsilon$ особистісний розвиток, формування суб'єктності як творчого ставлення до життєвого шляху [4].

Систематизація підходів до проблеми рефлексивного підходу професійної підготовки майбутніх фахівців послугувала підгрунтям для презентації авторського тлумачення сутності такого поняття, як рефлексія. На нашу думку, - це звернення уваги суб'єкта на самого себе і свою свідомість, зокрема, на продукти власної активності, а також будь-яке їх переосмислення. У навчальній діяльності - це самопізнання і здатність до самоорганізації студентів.

Одним з ефективних шляхів розв'язання проблеми розвитку рефлексії у студентів як майбутніх фахівців і професіоналів $\epsilon$ розроблення й упровадження до процесу вищої професійної освіти рефлексивно-діяльнісних моделей $\mathrm{i}$ технологій навчання, що передбачають як навчальні спецкурси та спецпрактикуми з психології рефлексії, тренінги 3 розвитку професійного самопізнання й самосвідомості, так i сучасні інноваційні рефлексивно-діяльні технології (рефлексику та рефлепрактику).

Найважливішу роль в організації рефлексивного освітнього середовища й розвитку рефлексивних здібностей студентів на всіх етапах професійної освіти (оптиці, адаптації, інтенсифікації та ідентифікації) виконує педагог. Для реалізації освітніх, управлінських функцій сучасний педагог повинен мати розвинену професійну рефлексію, що надає змогу зафіксувати суперечності освітнього процесу, творчо підійти до їх розв'язання, критично осмислити власні дії та віднайти шляхи впровадження інноваційних рішень.

У ході дослідження нами використовувалися авторські тести й опитувальники, які допомагають виміряти рівень розвиненості загальної рефлексивності (А. Карпов, В. Пономарьова), рефлексивного мислення (О. Анісімов) i професійної рефлексії (О. Рукавішнікова); виконати самооцінювання особистісних та професійно важливих якостей, а також рефлексивних умінь і навичок, що становлять зміст різних типів рефлексії особистісної, інтелектуальної, комунікативної, кооперативної, регулятивної та ін. (Т. Ратанова, Є. Рогов, В. Ряховський, М. Снайдер, Н. Шляхта та ін.); актуалізувати успіхи й обмеження професійної діяльності (М. Вудкок, Д. Френсіс);·з’ясувати мотиви професійної діяльності, оскільки рефлексія формується тільки за умов позитивного ставлення до виконуваної діяльності (К. Замфір, С. Ільїн, Н. Кузьміна, А. Реан та ін.).

3 метою вивчення рівня професійної рефлексії у курсантів льотних навчальних закладів було здійснено тестування за методикою О. Рукавішніковою [2]. Констатовано високий рівень сформованості рефлексивного компонента виявлено у 9,1\% учасників експерименту; середній рівень сформованості рефлексивного компонента зафіксовано у 56,5 \% досліджуваних; на низькому рівні сформованості рефлексивного компонента перебуває 34,4 \% учасників експерименту. 
Спираючись на одержані результати тестування та з огляду на актуальність проблеми рефлексивного управління освітнім процесом, нами було запропоновано майбутнім фахівцям традиційні та нетрадиційні психотехнічні вправи й рефлексивні завдання (Утвердження самоцінності, Образи мого «Я», На якій я сходинці?, Контраргументи, Зустріч із «саботажником» тощо). Крім того, пропонувалися способи розвитку рефлексивного самопізнання та саморегуляції (релаксація, концентрація, візуалізація, інверсія тощо), психотехнічні вправи й рефлексивні завдання для розвитку різних типів і видів рефлексії, рефлексивних умінь та навичок.

Після впровадження запропонованих методик високий рівень сформованості рефлексивного компоненту виявлено у 22,1\% учасників експерименту, середній рівень сформованості рефлексивного компоненту виявлено у 63,0 \% досліджуваних, на низькому рівні сформованості рефлексивного компонента перебуває 14,9 \% учасників експерименту.

Важливим є сформувати у майбутніх фахівців навички професійної рефлексії з метою застосування їх у подальшій професійній діяльності. Рефлексивні здібності забезпечують умови для саморозвитку особистості, iї самокорекції та творчої самореалізації, сприяють зростанню професійної майстерності й оволодінню новими знаннями зі спеціальності. Рефлексивна готовність виражена в ступені узагальненості й конкретизації механізмів самопізнання, саморозвитку та самореалізації особистості. Показником рефлексивної готовності слугує активність особистості в різних умовах і ситуаціях із їх перетворювання.

Професійна рефлексія містить у собі також готовність діяти в ситуаціях з високим ступенем невизначеності, гнучкість у прийняті рішень, прагнення до реалізації нововведень та інновацій, спрямованість на пошук нових, нестандартних засобів розв'язання професійних завдань, здатність переосмислювати свій професійний і особистісний досвід [3, с. 61].

У контексті дослідження зауважимо, що формування професійної рефлексії в майбутніх фахівців - необхідна умова з огляду на постійно зростаючі вимоги працедавців і науково-технічного прогресу. Вплив негативних чинників професійної діяльності вимагає від фахівця вмінь володіти своїми емоціями, вчасно адекватно реагувати на ситуацію, що склалася, контролювати психологічні та психофізіологічні реакції свого організму тощо.

Слід розуміти, що жодна методика або навіть кілька не розв'язують проблеми самопізнання й саморозвитку особистості та професіонала, але вони допомагають найкраще пізнати самого себе, озброюють системою орієнтирів, що допомагають окреслити основні риси власного образу, у разі необхідності полегшують коригування та їх розвиток, зокрема й відповідно до вимог обраної професійної діяльності.

Отже, різноманіття наукових позицій щодо рефлексії переконливо доводить, що рефлексія - невід'ємна частина та основа для формування висококваліфікованого та конкурентоспроможного фахівця. Досліджуваний феномен виявляється шляхом цілепокладання, аналізу, планування, контролю, оцінювання, через цілі, засоби, методи, процедури, результати. Рефлексія сприяє усвідомленню всіх компонентів саморегуляції та самоорганізації навчальної діяльності та $є$ її основою. Залежно від ступеня розвитку рефлексії наростає іiі прикладний потенціал у педагогіці. Наразі уявлення про значення рефлексії у професійній діяльності людини суттєво розширилися. Використання запропонованих матеріалів надасть змогу активізувати навчально-професійну діяльність майбутніх фахівців у напрямі розвитку й саморозвитку професійно важливих і особистісно значущих якостей.

У подальшому дослідження має на меті вивчення проблеми забезпечення якості професійної підготовки майбутніх фахівців на основі формування навичок рефлексії. 


\section{Література}

1. Закон України «Про вищу освіту» [Електронний ресурс] Режим доступу: http://zakon2.rada.gov.ua/laws/show/1556-18. 2. Личностная и профессиональная рефлексия: психологический практикум / сост. Г. С. Пьянкова; Краснояр. гос. пед. ун-т им. В. П. Астафьева. - Красноярск, 2012. - 125 с. 3. Марусинець М. М. Професійна рефлексія майбутнього вчителя початкових класів: теорія i практика формування : [монографія] / М. М. Марусинець. - Умань: ПП Жовтий О. О., 2012. - 420 с. 4. Мирошник О. Г. Педагогічна рефлексія як чинник вияву творчого потенціалу особистості вчителя / О. Г. Мирошник // Естетика і етика педагогічної дії: [збірник наукових праць]. Київ - Полтава : Інститут педагогічної освіти і освіти дорослих НАПН та ПНПУ імені В. Г. Короленка. - 2011. - Вип. 2 - С. 47-57. 5. Мишина Ю. Д. Психолого-педагогические условия развития ответственности у студентов педагогических вузов : дисс. ... канд. пед. наук : 13.00.08 «Теория и методика профессионального образования»/ Мишина Юлия Дмитриевна; Новосибирский государственный педагогический университет. - Томск, 2002. - 261 с. 6. Педагогический энциклопедический словарь / гл. ред. Б. М. Бим-Бад; ред. кол. М. М. Безруких, В. А. Болотов, Л. С. Глебова, Е. Л. Гончарова, Н. Н. Малофеев, Е. Г. Осиповский, А. В. Петровский. - Москва : Большая Российская энциклопедия, 2002. 528 с. 7. Про особливості формування навчальних планів на 2015/2016 навчальний рік. Міністерство освіти і науки України. Наказ № 47 від 26 січня 2015 року [Електронний pecypc]. - Режим доступу: http://zakon3.rada.gov.ua /laws/show/z 0132-15. 8. Русакова О. В. Формирование умений и навыков саморегуляции на основе рефлексии у младших подростков в процессе обучения : дисс. ... канд. пед. наук : 13.00.01 «Общая педагогика, история педагогики и образования» / Русакова Ольга Владимировна ; ГОУ ВПО «Вятский государственный гуманитарный университет». - Киров, 2009. - 209 с.

УДК 378.147

Олександр Прокопченко

\section{АНАЛІЗ МОЖЛИВОСТЕЙ ВИКОРИСТАННЯ ІНТЕРАКТИВНИХ ПРОГРАМНИХ ЗАСОБІВ КОМП'ЮТЕРНОЇ МАТЕМАТИКИ В НАВЧАЛЬНОМУ ПРОЦЕСІ ПІДГОТОВКИ ФАХІВЦІВ-ФАРМАЦЕВТІВ}

Прокопченко О. С. Аналіз можливостей використання інтерактивних програмних засобів комп'ютерної математики в навчальному процесі підготовки фахівців-фармацевтів.

У статті розглянуто можливості впровадження інтерактивних програмних засобів комп'ютерної математики в навчальний процес підготовки фахівців-фармацевтів. На прикладі курсу «Основи вищої математики та математичної статистики» (Запорізький державний медичний університет, I курс фармацевтичного факультету) надано методичні рекомендації щодо ефективного та оптимального використання сучасних інноваційних та когнітивних технологій у навчальному процесі.

Ключові слова: комп’ютерна математика, програмні засоби, інтерактивні методи, інноваційні освітні технології, когнітивні методи навчання.

Прокопченко A. Е. Анализ возможностей использования интерактивных программных средств компьютерной математики в учебном процессе при подготовке специалистов-фармацевтов.

В статье рассмотрены возможности внедрения интерактивных программных средств 